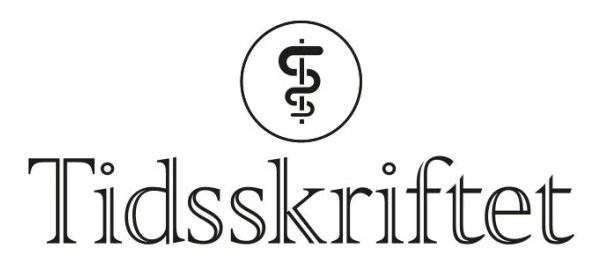

DEN NORSKE LEGEFORENING

\title{
Skriving på universitetsnivå
}

\author{
ANMELDELSER
}

\section{ANNE SPURKLAND}

Professor, Avdeling for anatomi

Institutt for medisinske basalfag

Universitetet i Oslo

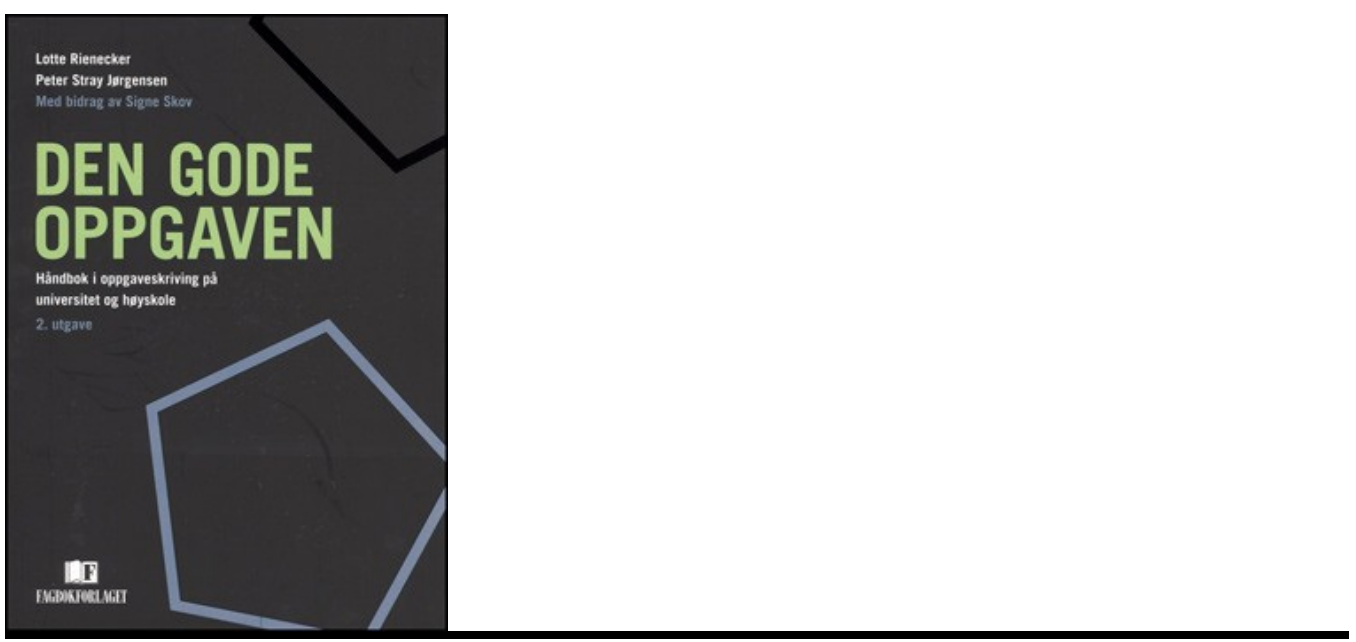

Rienecker, Lotte

Jørgensen, Peter Stray

Den gode oppgaven

Håndbok i oppgaveskriving på universitet og høyskole. 2. utg. 306 s, tab, ill. Bergen:

Fagbokforlaget, 2013. Pris NOK 449

ISBN 978-82-450-1329-0

Dette er en praktisk håndbok i skriving som retter seg mot studenter innenfor alle fagfelt på universitetsnivå. Den er omfangsrik, men skal ikke nødvendigvis leses fra perm til perm.

Forfatterne har lang erfaring med veiledning av studenter i oppgaveskriving. Lotte Rienecker er psykolog og tilknyttet Danmarks tekniske universitets LearningLab DTU, mens Peter Stray Pedersen er rådgiver i universitetspedagogikk ved Århus universitet. 
I første kapittel presenterer de "pentagonen», en metafor som går igjen i resten av teksten. Pentagonens fem hjørner tilsvarer hvert av fem elementer som må være til stede i en god oppgave:

- 1 Problemformulering (hvorfor skriver du?)

- 2 Formål (hvorfor spør du?)

- 3 Empiri (hva spør du på grunnlag av?)

- 4 Teori og metoder (hva spør du med?)

- 5 Fremgangsmåte (hvordan spør du?)

Med dette som utgangspunkt analyserer forfatterne eksempler på studentoppgaver som har fått svært god eller ikke så god karakter, og forklarer hvilke formuleringer og begreper det er naturlig å bruke i de ulike hjørnene av pentagonen. De gir også eksempler på hvordan pentagonen kan brukes innenfor ulike fag og fagtradisjoner. Leseren får konkrete råd om hvordan man bør arbeide gitt oppgavens rammer. Avhengig av om studenten er fersk (bachelornivå) eller erfaren (masternivå), stilles det ulike krav til en god oppgave.

Det legges vekt på at skrivearbeidet under studiet har direkte relevans til yrkeslivet siden. Det å lære seg å skrive godt er noe av det viktigste man gjør i høyere utdanning. En underliggende forutsetning er at det i høyere utdanningsløp skrives mye og at studentene stadig får mulighet til å utvikle og forbedre skriveferdighetene. Det slo meg at medisinstudiet er av de ytterst få høyere utdanningene der studentene ikke lærer å skrive. Studieplanen gir ikke rom for å skrive tekster og få tilbakemelding på dem fra lærer. Den eneste konkrete skriveerfaringen studentene har før de kommer til særoppgaven, er knyttet til skriftlige eksamener. Som ferdig utdannet lege er det likevel ofte behov for å skrive, slik som journalnotater, epikriser, attester og legeerklæringer.

Jeg opplever boken som litt overveldende og tror ikke at den er egnet til selvstudium for ferske studenter. Til det er den for omfattende og har for rotete layout.

Publisert: 11. mars 2014. Tidsskr Nor Legeforen. DOI: 10.4045/tidsskr.13.16o9

(C) Tidsskrift for Den norske legeforening 2023. Lastet ned fra tidsskriftet.no 26. april 2023. 